\title{
Geomorphosites of Poland - the role played by the Central Register of Geosites
}

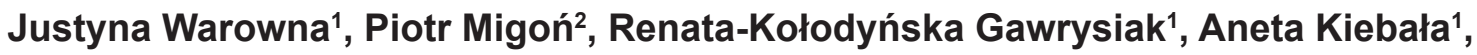 \\ Wojciech Zgłobicki ${ }^{1}$ \\ ${ }^{1}$ Department of Geology and Lithosphere Conservation, Maria Curie-Skłodowska University, Lublin, Poland, jwarowna@umcs.pl \\ ${ }^{2}$ Department of Geography and Regional Development, University of Wrockaw, Poland
}

\begin{abstract}
Poland is a country of considerable geomorphological diversity and includes a range of physical landscapes, from high mountains through uplands, plains, glaciated lowlands, large river valleys, to coasts. Within them, numerous localities may be considered as geomorphosites, illustrating key stages in the geomorphic evolution of the territory, classic landforms and the recent operation of geomorphic processes. The only database that aims to cover all geosites in Poland, including sites of geomorphological interest, is the Polish Central Register of Geosites (PCRG), managed by the state geological survey - the Polish Geological Institute (PIG). Among more than 2200 geosites recorded about $30 \%$ can be considered as geomorphosites. Their spatial coverage is very uneven. Most are located in the upland belt of southern Poland (40\%) and in northern part of the country, within the extent of the late Pleistocene ice sheet (29\%), while the Carpathians are under-represented. Thematically, geosites illustrating various examples of denudational relief dominate (45\%). Significantly less common are glacifluvial (13\%), glacial (11\%) and fluvial (10\%) landforms. Tors and residual hills are most common among geomorphosites (205 sites), followed by moraines (52), dunes (49), gullies and their systems (45) and river valleys (34). Thus, PCRG does not yet adequately reflect the diversity of the geomorphological heritage of Poland.
\end{abstract}

Key words: Geomorphosites, geoheritage, geodiversity, Poland

\section{Introduction}

Within the geoscientific community there is an increasing awareness that outreach activities and popularization of science for general public have critical importance if the messages delivered by scientists are to be successfully spread. One among the means to reach the public are geosites - specific locations where various components of geoheritage may be observed, enjoyed, and explained. According to Reynard (2004), they are of particular importance for the comprehension of the history of the Earth, but some anthropic sites, e.g. mine galleries, are included. Furthermore, he divides geosites into 'active', where processes at work can be witnessed, and 'passive', showing the legacy of past events and processes. For geomorphology - the science of the scenery (Fairbridge 1968) - the concept of geosites is particularly applicable and the term geomorphosite was coined by Panizza (2001) to highlight the distinctiveness of sites of special geomorphological interest. Geomorphosites can represent different types: landforms sensu stricto (e.g. tors, dolines, waterfall steps), rock and sediment outcrops providing insights into the origin of the land surface (hence, quarries and gravel pits may be valuable geomorphosites), as well as viewing points offering an opportunity to examine landform diversity at a larger scale (see Giusti et al. 2011).

Some authors argue that a designated geomorphosite should be a site illustrating a broader context of geomorphology and the linkages of landforms with ecological (biological) or cultural values. Thus, Reynard (2005) considers geomorphosites as places where specific landforms have acquired a special scientific, cultural, aesthetic, and socio-economic value due to human perception and exploitation, while Panizza and Piacente (2005) suggest that three general themes are associated with geomorphosites: research within geosciences, integration with the wider cultural environment, and artistic connotations. This view is reflected in some numerical approaches to evaluate potential geomorphosites, where an 'additional value' (aesthetic, ecological, historical etc.) is considered alongside the scientific, geomorphological value.

Designation and management of geomorphosites is inevitably associated with a range of practical issues. These include selection of sites to be presented, their representativeness, the level and quality of information offered, provision of adequate access, avoidance of potential conflict with interest of nature conservation etc. To agree on the information content is not a trivial exercise, as - first - 
geoscience is not an easy subject and abound in technical language, and second - different categories of end-users may be distinguished. At least three groups may be identified: (a) professionals, (b) lay-people driven by curiosity, with little specialist background but open mind and willingness to learn, (c) tourists who visit the places without a priori realizing their geoscientific value. With such diverse backgrounds it is virtually impossible to have one successful interpretative approach, especially in the field, at the site.

In the era of digital media and electronic communication, web-accessible open databases of geosites play an increasing role, particularly for professionals and motivated lay-people. They offer the first insight into geodiversity of an area, help to plan geotourist routes, and act as virtual guides (Zgłobicki, Baran-Zgłobicka, 2013). Ideally, they contain information about both the scientific value of the site itself, as well as practical issues how to get there and around. In Poland, a country of considerable geodiversity, a number of initiatives in this respect have been launched in the past, at national or regional level, albeit with mixed success. One such initiative, coordinated at the central level and most comprehensive among all, is the Polish Central Register of Geosites (PCRG), run and managed by the state geological survey - the Polish Geological Institute (PGI). Although the database is so far available in Polish only, it is the only one widely accessible, with an English version planned in the next years. The primary aim of this paper is therefore to evaluate how geomorphosites are represented among more than 2,200 localities registered in the database and how the PCRG may serve geomorphological community. The second aim of this exercise is to identify gaps in the current register, so that they can be filled in the future.

\section{Geomorphological diversity of Poland}

\section{Geological background}

Geologically, Poland is located at the junction of three major structural units of European extension which are of different age and origin, hence contain different rock records (Stupnicka 1987; Słomka 2008) (Fig. 1). The northeast belongs to the East European Platform which consists of a Precambrian shield covered by younger sedimentary series, spanning the period from the Late Proterozoic to the Quaternary. The NE part of the country experienced a number of ice sheet advances during the Pleistocene and it is these relatively recent glacial and fluvioglacial deposits that form most of the topographic surface.

The majority of the country is a part of Palaeozoic platform which again consists of a basement, ultimately consolidated in the Carboniferous, and younger cover deposits. Quaternary deposits hide much of the older formations. In two regions, the Sudetes in the extreme southwest and the Holy Cross Mountains in the south-central

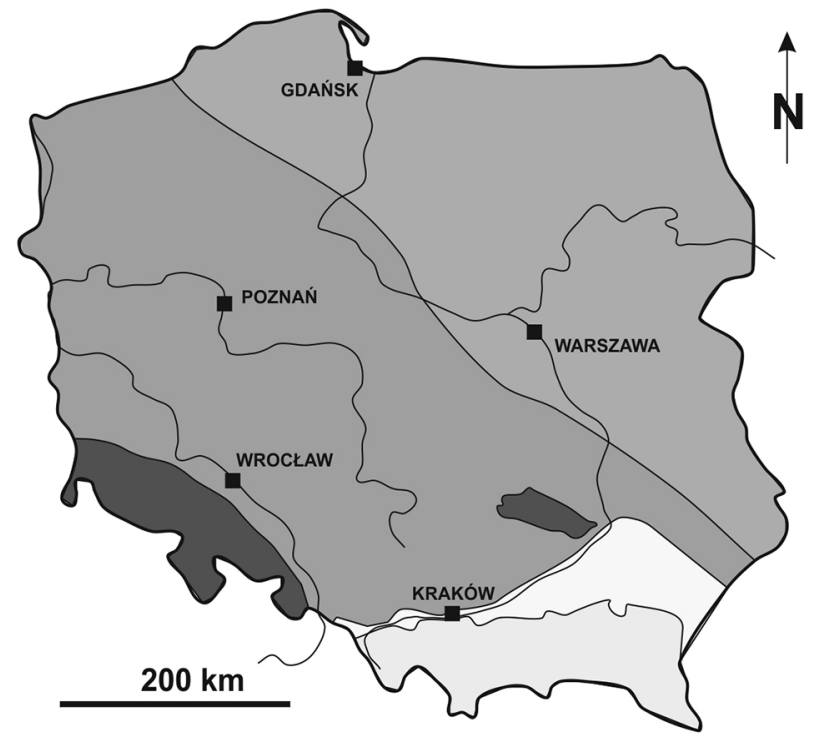

East European Platform

Palaeozoic platform

Palaeozoic basement exposed

\section{Alpine fold belt: the Carpathians}

Fore-Carpathian Depression

Fig. 1. Main geological structural units of Poland

Poland, basement rocks can be seen at the surface. In the Sudetes these are mainly metamorphic rocks (gneiss, mica schist, greenstone), accompanied by numerous granite intrusions, mainly of Carboniferous age, and volcanic formations of different ages. In the Neogene, the old Palaeozoic orogen of the Sudetes was rejuvenated and differentially uplifted to form the contemporary horstand-graben structure. In the Holy Cross Mountains sedimentary rocks prevail (sandstone, conglomerate, limestone). Post-Hercynian deposits are mostly of marine origin and include widespread limestone, chalk, sandstone, and mudstone. Jurassic and Cretaceous formations are particularly widespread in central and eastern part of Poland, whereas Cretaceous sandstone is a characteristic lithology for the Sudetes, although its extent is relatively limited.

The third structural unit occurs in the south-east and is a part of the Carpathian arc, itself a component of Alpine orogenic system. Four sections can be distinguished here: the Inner Carpathians represented by the Tatra Mountains built of a Palaeozoic basement core overlain by various sedimentary rocks of Mesozoic age, the Pieniny Klippen Belt with dominant Mesozoic limestone, the Outer Carpathians built of Cretaceous to Palaeogene flysch arranged into several nappes stacked one upon another, and the Fore-Carpathian Depression filled mainly with Miocene deposits. The Carpathians acquired their general structure during Palaeogene/Neogene transition, although vertical and horizontal tectonic movements have followed until the present-day. 


\section{Landforms and landscapes}

The geomorphological landscape of Poland is genetically very diverse (Gilewska 1999, Mojski 2005). It also varies in terms of age of major landforms (Klimaszewski 1980) and altitude, being arranged into a series of broadly parallel belts of east-west extension (Fig. 2). Going from south to north these are the following ${ }^{1}$ :

- mountain terrains of the Carpathians in the south-east and the Sudetes in the south-west. These can be further subdivided into three distinctively different types of morphology:

- Tatra Mountains which are the only high-mountain area in Poland, rising to 2,499 $\mathrm{m}$ a.s.l. It shows an Alpine type of relief, with pointed peaks, sharp crests and deeply incised valleys, although the altitude is insufficient to allow for contemporary glacier development. Nevertheless, inherited glacial landforms are widespread. However, the area of the Tatra Mountains is only $175 \mathrm{~km}^{2}$, which is less than 0.1 per cent of Poland.

- Beskidy Mountains which correspond to the flysch-built Outer Carpathians. Their highest peak reaches 1,725 $\mathrm{m}$ a.s.1., but most individual ranges reach 900-1,200 $\mathrm{m}$ a.s.l. Except the highest peaks, Beskidy are within the forest belt. Solid rock outcrops are not very common, while landslides are extremely abundant. Non-karstic caves are often associated with crown areas of landslides.

- Sudetes which represent a horst-and-graben type of morphology developed upon bedrock which is highly diverse lithologically. The highest peak reaches 1,602 $\mathrm{m}$ a.s.l. A multitude of minor structu-

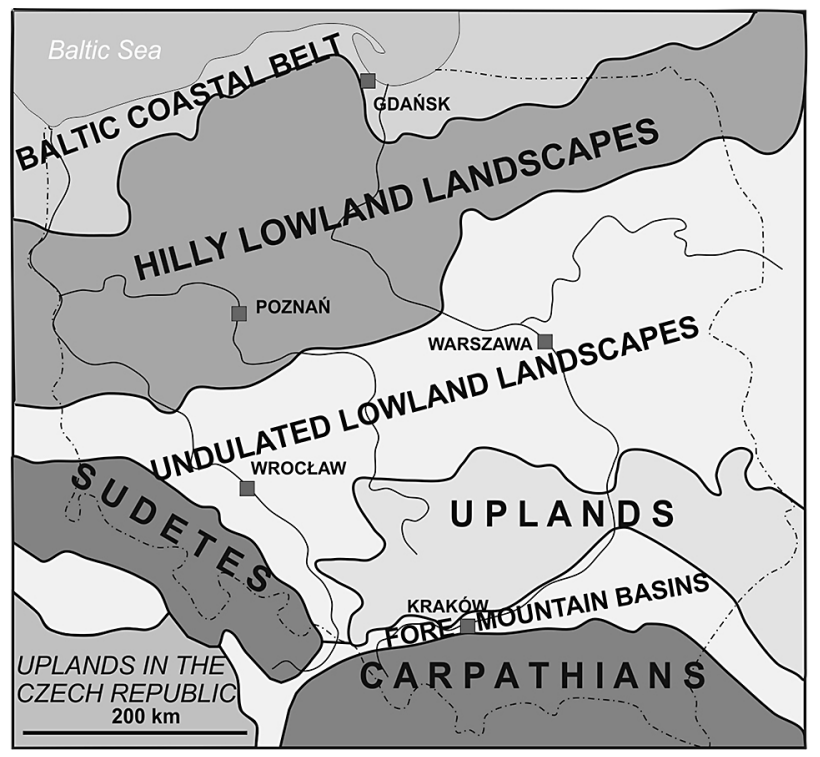

Fig. 2. Landscape diversity of Poland

Space does not permit more thorough characterization of different geomorphological regions of Poland, nor inclusion of an extensive bibliography. Therefore, only the key regional features are emphasized, to give an overview of the variety of the Poland's physical landscape. ral landforms occurs within the Sudetes, including tors, mesas, escarpments and rock-controlled residual hills. River gorges are numerous. Inherited glacial landforms occur at the highest altitudes and geomorphic legacy of cold climate conditions of the Pleistocene is widespread. In front of the Sudetes, on a downthrown block, an early Cenozoic inselberg landscape survived.

- fore-mountain basins. These occur along the margin of the Carpathians and are characterized by flat to gently rolling relief developed upon sedimentary rocks of low resistance, covered by Quaternary glacial, fluvioglacial, fluvial, and aeolian deposits. The longest Polish river, Wisła (Vistula), crosses the basins.

- uplands. The upland belt extends from the Odra river to the west to the Ukrainian border in the east and is cut by the Wisła valley. Altitudes are within the 300-500 $\mathrm{m}$ a.s.1. range, culminating in the Holy Cross Mountains at $612 \mathrm{~m}$ a.s.1. Diverse lithology has given rise to distinctive relief types, including limestone karst plateaus, gypsum and chalk karst terrains, cuesta ridges, and ridge-and-vale topography. On thick patches of Pleistocene loess gully erosion is very efficient. The entire upland belt was within the extent of Middle Pleistocene ice sheet advance some 450-400 ka ago, but glacial deposits have been largely stripped since and glacial landforms erased.

- flat to undulated lowland landscapes. They occur in central Poland and represent the least diverse geomorphic unit of the country. Surface deposits are predominantly of glacial origin, but the last advance of the Scandinavian ice sheet occurred c. 200 ka ago and any distinctive glacial landforms from that time have been obliterated by subsequent denudation. Lowlands are crossed by major river valleys and in a few of them channels escaped regulation and represent natural fluvial landscapes, very rare in central and western Europe. Locally inland dune fields can be found, now largely stabilized by vegetation.

- hilly lowland landscapes. The northern hilly lowland owes its origin to erosional and depositional glacial processes during the last ice sheet advance, 25 to 11 ka ago. Glacial landforms are distinctive and include frontal moraines, marginal depressions, moraine plateaus, subglacial troughs, eskers, drumlin fields, and outwash plains. Erratic boulders of Scandinavian rocks are abundant. Elevations are up to $329 \mathrm{~m}$ a.s.l. Many glacial depressions are occupied by lakes, the total number of which approaches 10,000.

- Baltic coast. The Polish sector of Baltic coastline is more than $500 \mathrm{~km}$ long and is made of alternating stretches of sandy beaches backed by coastal dunes, now mostly forested, and cliffs developed in poorly consolidated sediments of Quaternary age. Their height is from a few to more than $60 \mathrm{~m}$. Coastal landslides are common and there many examples of their negative impact on infrastructure and buildings. Coastal depositional landforms include beaches, spits 
and barriers, the latter separating coastal lakes from the open sea.

\section{Central Register of Geosites and methods of study}

The Polish Central Register of Geosites (PCRG), is managed by the state geological survey, i.e. the Polish Geological Institute - National Research Institute. This register is part of the Central Geological Database ${ }^{2}$ and contains data of more than 2200 geosites. It allows users to search for sites in two categories: by administrative units (3 levels) or by structural (geological) units or by sheets of the Detailed Geological Map of Poland. The second category is a combination of 6 characteristics, namely:

- type of site with subcategories: landform features (forms of accumulation and denudation origin), water sites, geological outcrops (natural and artificial), palaeontological sites, remnants of mining activity, sites with interesting minerals and rocks, and other,

- standing of the site (local, national, international),

- conservation status,
- integrity,

- location relative to tourist trails,

- accessibility.

Details of the specific sites are displayed on eight consecutive screens: general information (name of the site, type, location, administrative unit, geological unit, geographical region, geographical coordinates); physical features (dimensions); current condition (conservation, accessibility); geological characteristics of the site); visual documentation (photographs, sketches, section); studies (author, updates); bibliography and map (location including GPS coordinates). Abridged information in English is also available in English on the Central Geological Database website, where after generating a map of geosites (with various backgrounds: rivers, lakes, administrative units, geographical regions) and clicking a specific site, general information is displayed.

The present study is a review of geosites in the following categories: a) landform features (forms of accumulation and denudation origin); b) other. Based on the PCRG data, the individual sites were assigned to the relief zones distinguished. The origins and the type of form was identified for each geomorphosite. On this basis, comprehensive lists were prepared.

Table 1. A listing of geomorphosites in the PCRG database (as of 06.2013)

\begin{tabular}{|c|c|c|c|c|c|c|c|}
\hline & Carpathians & Sudetes & Uplands & $\begin{array}{c}\text { Hilly } \\
\text { lowland } \\
\text { landscapes }\end{array}$ & $\begin{array}{c}\text { Lowland } \\
\text { (old-glacial) } \\
\text { landscapes }\end{array}$ & Baltic coast & Total \\
\hline \multicolumn{8}{|c|}{ Fluvial landforms } \\
\hline River channels & 0 & 0 & 4 & 2 & 1 & 0 & 7 \\
\hline River valleys & 1 & 1 & 7 & 25 & 0 & 0 & 34 \\
\hline Alluvial fans & 0 & 0 & 4 & 0 & 1 & 0 & 5 \\
\hline Oxbows & 0 & 0 & 4 & 2 & 3 & 0 & 9 \\
\hline River terraces & 0 & 0 & 1 & 2 & 1 & 0 & 4 \\
\hline Gorges & 0 & 2 & 2 & 2 & 1 & 0 & 7 \\
\hline Waterfalls & 1 & 2 & 3 & 0 & 0 & 0 & 6 \\
\hline Total & 2 & 5 & 25 & 33 & 7 & 0 & 72 \\
\hline \multicolumn{8}{|c|}{ Tectonic landforms } \\
\hline Tectonic grabens & 0 & 1 & 0 & 0 & 0 & 0 & 1 \\
\hline $\begin{array}{l}\text { Fault-generated escarp- } \\
\text { ments }\end{array}$ & 0 & 0 & 2 & 0 & 0 & 0 & 2 \\
\hline Total & 0 & 1 & 2 & 0 & 0 & 0 & 3 \\
\hline \multicolumn{8}{|c|}{ Landforms of denudational origin, including hillslope water erosion } \\
\hline Weathering mantles & 1 & 2 & 0 & 0 & 0 & 0 & 3 \\
\hline Tors and residual hills & 12 & 37 & 152 & 6 & 2 & 0 & 205 \\
\hline Escarpments & 1 & 0 & 5 & 7 & 14 & 0 & 27 \\
\hline Lava flow plateaus & 0 & 2 & 0 & 0 & 0 & 0 & 2 \\
\hline Gullies & 1 & 0 & 32 & 7 & 3 & 2 & 45 \\
\hline $\begin{array}{l}\text { Landforms arising from } \\
\text { mass movement }\end{array}$ & 21 & 3 & 5 & 0 & 0 & 2 & 26 \\
\hline Total & 35 & 40 & 194 & 20 & 19 & 4 & 312 \\
\hline \multicolumn{8}{|c|}{ Karst landforms } \\
\hline Dolines & 0 & 0 & 3 & 0 & 0 & 0 & 3 \\
\hline Karst valleys & 0 & 0 & 1 & 0 & 0 & 0 & 1 \\
\hline Springs & 0 & 1 & 0 & 0 & 0 & 0 & 1 \\
\hline Minor corrosional features & 0 & 3 & 0 & 0 & 0 & 0 & 3 \\
\hline
\end{tabular}

\footnotetext{
geoportal.pgi.gov.pl/portal/page/portal/geostanowiska/
} 
Table 1. cont.

\begin{tabular}{|c|c|c|c|c|c|c|c|}
\hline & Carpathians & Sudetes & Uplands & $\begin{array}{c}\text { Hilly } \\
\text { lowland } \\
\text { landscapes }\end{array}$ & $\begin{array}{c}\text { Lowland } \\
\text { (old-glacial) } \\
\text { landscapes }\end{array}$ & Baltic coast & Total \\
\hline Caves & 2 & 5 & 24 & 0 & 0 & 0 & 31 \\
\hline Total & 2 & 8 & 33 & 0 & 0 & 0 & 43 \\
\hline \multicolumn{8}{|c|}{ Glacial landforms } \\
\hline Moraines & 0 & 0 & 0 & 40 & 12 & 0 & 52 \\
\hline Drumlins & 0 & 0 & 0 & 3 & 0 & 0 & 3 \\
\hline Push moraines & 0 & 0 & 0 & 13 & 0 & 0 & 13 \\
\hline $\begin{array}{l}\text { Kettle holes/dead ice } \\
\text { hollows }\end{array}$ & 0 & 0 & 0 & 5 & 0 & 0 & 5 \\
\hline Total & 0 & 0 & 0 & 61 & 12 & 0 & 73 \\
\hline \multicolumn{8}{|c|}{ Glacifluvial landforms } \\
\hline Subglacial channels & 0 & 0 & 0 & 25 & 2 & 0 & 27 \\
\hline Sandurs & 0 & 0 & 0 & 7 & 4 & 0 & 11 \\
\hline Eskers & 0 & 0 & 0 & 17 & 5 & 0 & 22 \\
\hline Marginal valleys & 0 & 0 & 0 & 2 & 3 & 0 & 5 \\
\hline Kames & 0 & 0 & 0 & 21 & 1 & 0 & 22 \\
\hline Total & 0 & 0 & 0 & 72 & 15 & 0 & 89 \\
\hline \multicolumn{8}{|c|}{ Litoral landforms } \\
\hline Cliffs & 0 & 0 & 0 & 0 & 0 & 23 & 23 \\
\hline Beaches & 0 & 0 & 0 & 0 & 0 & 2 & 2 \\
\hline Spits & 0 & 0 & 0 & 0 & 0 & 2 & 2 \\
\hline Deltas & 0 & 0 & 0 & 0 & 0 & 2 & 2 \\
\hline River mouths & 0 & 0 & 0 & 1 & 0 & 5 & 6 \\
\hline Inverted delta & 0 & 0 & 0 & 0 & 0 & 1 & 1 \\
\hline Total & 0 & 0 & 0 & 1 & 0 & 35 & 36 \\
\hline \multicolumn{8}{|c|}{ Aeolian landforms } \\
\hline Dunes & 0 & 0 & 17 & 9 & 14 & 9 & 49 \\
\hline Loess escarpments & 0 & 0 & 3 & 0 & 0 & 0 & 3 \\
\hline Loess plateaus & 0 & 0 & 4 & 0 & 0 & 0 & 4 \\
\hline Total & 0 & 0 & 24 & 9 & 14 & 9 & 56 \\
\hline Total & 39 & 54 & 273 & 196 & 67 & 48 & 677 \\
\hline
\end{tabular}

\section{Results and discussion}

The analysis of data concerning CRGP-listed sites indicates that geomorphosites account for about $30 \%$ sites in the database. Most of them are located within the upland belt (40\% geomorphosites) and young glacial areas (29\% geomorphosites). The Carpathians are the least represented: the number of geosites here is visibly lower than in the Sudetes despite their smaller area (Table 1).

The most numerous in the CRGP database are geomorphosites associated with forms of denudational and erosional origin (45\% geomorphosites), most of which occur within the upland belt. The most frequently occurring landforms are tors and residual hills (205 sites) as well as young erosional forms - gullies (45 sites). In terms of number, these are followed by geomorphosites associated with fluvioglacial (13\%), glacial (11\%) and fluvial $(10 \%)$ relief. The largest number of such sites occurs in areas with young glacial, old glacial and upland relief. Moraines (52 sites), river valleys (34 sites) and subglacial channels (23 sites) are the most common among geomorphosites. Aeolian landforms, primarily dunes, account for about $8 \%$ of all geomorphosites analysed. Litoral and karst landforms have a clearly smaller representation (5\% and $6 \%$ of geomorphosites respectively). Basically, the database does not contain any landforms of tectonic origin (Table 1).

The distribution of geomorphosites in landscape zones (relief zones) is as follows):

a) Tatra Mountains - no sites in the database. Therefore, elements of mountain glacial relief, high-mountain karst and fluvial relief are not represented in the Polish part of the Carpathians.

b) Beskidy Mountains - within this flysh belt, the most numerous landforms are of denudational origin arising from mass movements: mainly landslides and caves formed as a result of gravitational processes. These are followed by numerous tors and residual hills. The remaining groups include individual landforms (Table 1), definitely too few given the morphological and elevation diversity of the area. Within the calcareous Pieniny Klippen Belt, only 2 karst caves are listed. The peculiar, "insular" mountains of Beskid Wyspowy, of tectonic and denudational origin, are not represented in the catalogue either. A greater number of sites occurs in the Western Car- 
pathians and their foothills, while the Eastern Carpathians are poorly represented.

c) Sudetes - on the one hand, the proportions between various types of geosites reflect the key relief characteristics of the Sudetes, namely the predominance of denudational relief with numerous isolated hill elements arising from the varying rock resistance (Fig. 3 ); on the other hand, elements of tectonic relief are not exposed. The number of karst landforms is high in relation to the small proportion of limestone in the geological structure of the area. What is missing on the list of important themes are the structural relief landforms in granite rocks - domed hills, rocks, conglomerates, non-karst caves; well-known landforms of denudational origin in the sandstones of the Table Mountains (rock labyrinths, monadnocks, residual sandstone conglomerates, morphological steps); periglacial morphogenesis landforms occurring in the highest parts of the Karkonosze mountains and the Śnieżnik massif (cryoplanation terraces, block covers, structural soils) and landforms linked with mountain glaciation. The Karkonosze and Góry Stołowe, the most valuable in terms of inanimate nature, are the least represented in comparison with the other regions.

d) Fore-mountain basins - just a few geosites were distinguished here, namely valley sides or hill slopes within which geological outcrops occur. Isolated horst hills in the narrowing between the Sandomierz Lowland and Oświęcim Basin were treated as geological sites.

e) Uplands - the greatest concentrations of sites within the mesoregion system occurs in the Kraków-Częstochowa Upland, Roztocze and the western part of the Lublin Upland. The dominant landforms are tors and residual hills of denudational and karst origin, particularly within the Kraków-Częstochowa Upland. Another group are loess landforms (48) among which gullies predominate, particularly in the Lublin Upland (Fig. 4). In the remaining loess areas, only 6 sites were distinguished, which does not reflect the characteristics or the frequency of these landforms. Another group of

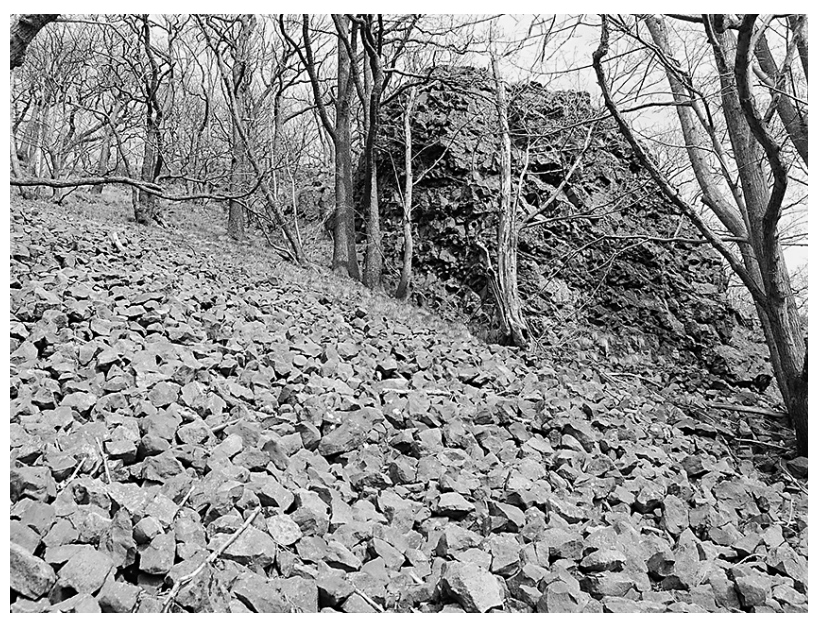

Fig. 3. Tor and rockfield at Ostrzyca Proboszczowicka (Sudetes) landforms are caves: only 20 caves out of about 1400 in the Kraków-Częstochowa Upland, and a few from each of the other regions have been selected so far (Table 1). Surface karst landforms are poorly represented in all regions. There is a definite lack of quite numerous kart springs, small landforms (dolines, pockets) and large-area landforms (on marl and gypsum). River valleys, followed by channels and oxbows, have the greatest share among fluvial landforms. However, the inventory of sites is very incomplete. Glaciation occurred in the uplands in the earlier part of the Pleistocene. Hence the glacial landforms are strongly denuded and they are not listed with the exception of a glacifluvial form: the Tarłów esker, very well visible in relief maps and in the actual landscape. Dunes are the most common among Aeolian forms due to the presence of sand covers of glacifluvial origin and valley sediments.

f) Flat to undulating lowland landscapes - it is an old glacial zone with highly eroded relief and very flat landscapes. There is a small number of quite evenly distributed geosites. The most numerous are denudational landforms, including escarpments of marginal valleys: 14 out of 19 sites (Table 1). As regards glacial landforms, low hills of residual moraines and frontal moraine zones predominate, followed by glacifluvial landforms: sandur plains and erosional marginal valleys. Dunes developed on the former sandurs and marginal valleys. However, the number of interesting sites should be higher. The numerous relief forms of fluvial origin are characteristic feature of the landscapes (Fig. 5) but there are not represented in the register.

g) Hilly lowland landscapes - young glacial zone of an undulating and hilly character. More than 130 geosites are concerned with landforms linked with the withdrawal of the last ice sheet in Poland. The predominant landforms of accumulation origin are frontal moraines and moraines with glacitectonic characteristics that are linked with geological outcrops. Subglacial channels are the most numerous among erosional landforms. Marginal valley landforms and sandurs are

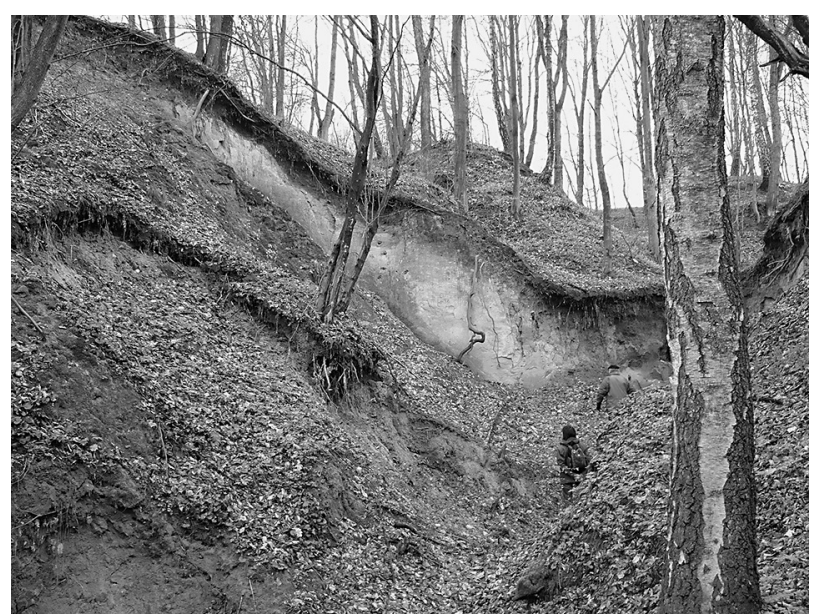

Fig. 4. Loess gully (Lublin Upland) 


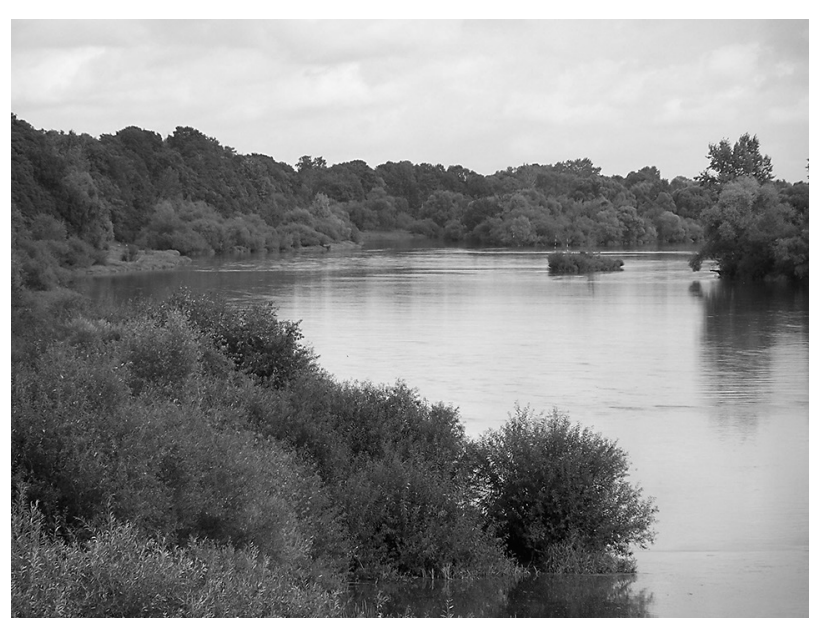

Fig. 5. Bug river valley (vicinity of Nur)

not very numerous because of their large size, which makes it difficult to find an appropriate observation point. Individual dunes and dune fields, also in marginal valley location, were observed on the sandurs. Eskers also occur (Fig. 6). As living and young landforms, the river valleys in this belt are the most numerous group among fluvial landforms, while the other elements are represented to a smaller extent. Particularly noteworthy are the rare and very young "residual hill" landforms developed as a result of the cementing of glacifluvial sediments and removal of non-cemented particles. In one case, a cave form developed.

h) Baltic coast - in this zone, cliffs primarily occur as places with geological outcrops with landslides and rockfalls; the cliffs are well-represented both on the side of the open sea and the Gdańsk Bay; a few are marked, e.g. at the Bay of Szczecin. The beaches (very common) and sandbars (spits) are poorly exhibited, unlike the sand dunes that developed behind them. Among estuaries, there are a few estuaries issuing into the sea as well as the only inverted delta on the Polish coast - the delta of the Świna. The current mouth of the Vistula, in the form of an artificial canal, has also been included as a peculiar, anthropogenic landform.

It should be emphasised that until now, geosites have been entered into the database in connection with the implementation of specific projects, e.g. documentation of geoparks, and not in a systematic manner. This is why national parks are represented to a very limited extent (particularly in areas of geomorphological interest in Poland - the Tatras, Karkonosze, Góry Stołowe, there is a total absence of geosites or only single sites appear).

At the initial stage, the database was primarily built by geologist who paid less attention to geomorphological sites or ignored the geomorphological aspects of geological sites. This is manifested in the general typological approach to the PCRG. There are landforms as well as natural rock outcrops among which many are also landform features (and geomorphological content can be more important than strictly geological content).

In the case of individual genetic groups of landforms, there is a very significant overrepresentation within ge-

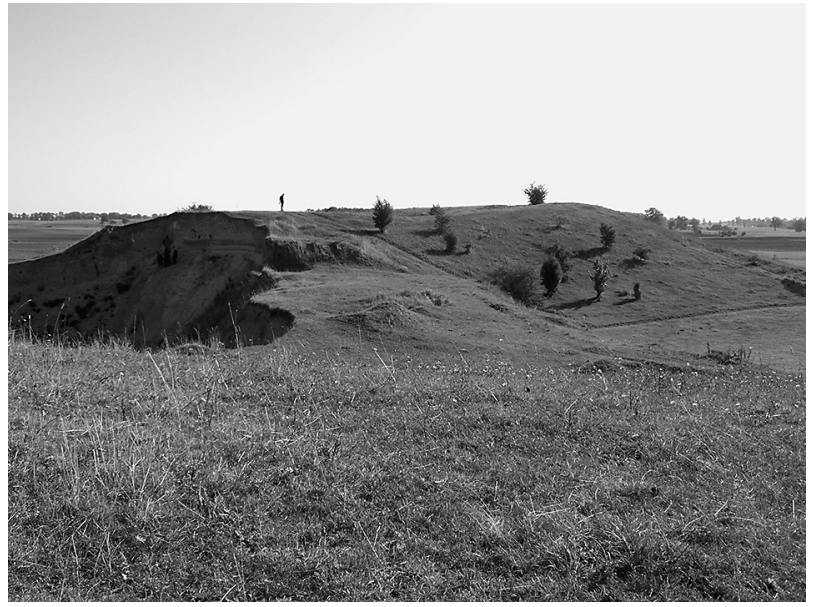

Fig. 6. Wielowiczek esker (Pomeranian Lakeland)

netic groups, i.e. a predominance of one kind of landform fluvial landforms - river valleys (47\% of geosites); karst landforms - caves (83\% of geosites); litoral landforms cliffs ( $63 \%$ of geosites); Aeolian landforms - dunes $(87 \%$ geosites). Some types of geomorphosites are very poorly represented: waterfalls, beaches, tectonic landforms, karst landforms (except for caves). Attention should also be paid to the relatively low number of geomorphosites associated with fluvial relief despite their widespread occurrence within all types of relief. Anthropogenic landforms are not listed in the PCRG either.

It should be underlined that nowadays PCRG is the best source of information for geotourists. Database contains easy accessible data for the whole country. It is especially important to supplement the register with the representative data for the geomorphological heritage of Poland.

The analysis of data in the Register indicates the need for the following actions (challenges for the future):

- to supplement the PCRG with sites in national parks,

- to make sure that the sites in a given region better correspond to the diversity of relief in that region (province),

- to complement descriptions for sites that are not nominal geomorphosites,

- to amend the existing descriptions that contain mistakes or that do not fully describe the geomorphological richness of a given site.

\section{Conclusions}

1. The Polish Central Register of Geosites is the only publicly available internet database containing nearly 700 geomorphosites.

2. In its current form, the register does not reflect the actual spatial and genetic diversity of Poland's geomorphological heritage.

3 . In the future, the list of geosites will have to be supplemented with representative geomorphosites, primarily from mountain areas, while the existing descriptions will have to be amended. 


\section{References}

Fairbridge R.W. (ed.), 1968. The Encyclopedia of Geomorphology. Reinhold Book Corporation, New York-Amsterdam-London.

Gilewska S., 1999. Rzeźba. In: L. Starkel (ed.), Geografia Polski. Środowisko przyrodnicze (2nd ed.). Wydawnictwo Naukowe PWN, Warszawa: 243-288.

Giusti C., Joyeux O., Toquet E., 2011. Geotope, geofacies and geosystem: how to introduce people to geomorphological landscapes through geomorphosites? The Aiguilles Rouges National Nature Reserve, Chamonix - Mont-Blanc (Haute-Savoie, France). In: International Symposium on Geosite Management. Managing Geosites in Protected Areas. Savoie - Mont Blanc, Conference 7-9 September 2011. Abstract Booklet - Livret des Résumés: 18-19.

Klimaszewski M., 1980. Bezwzględny wiek rzeźby terytorium Polski. Studia Geomorphologica Carpatho-Balcanica 14: 3-16.

Mojski J.E., 2005. Ziemie polskie w czwartorzędzie. Zarys morfogenezy. Państwowy Instytut Geologiczny, Warszawa.
Panizza M., 2001. Geomorphosites: concepts, methods and examples of geomorphological survey. Chinese Science Bulletin, Suppl. 46: 4-6. http://dx.doi.org/10.1007/BF03187227

Panizza M., Piacente S., 2005. Geomorphosites: A bridge between scientific research, cultural integration and artistic suggestion. Il Quaternario 18(1): 3-10.

Reynard E., 2004. Geosite. In: A.S. Goudie (ed.), Encyclopedia of Geomorphology, vol. 1. Routledge, London: 440.

Reynard E., 2005. Geomorphological sites, public policies and property rights. Conceptualization and examples from Switzerland. Il Quaternario 18(1): 323-332.

Słomka T., 2008. Geodiversity of Poland. Przegląd Geologiczny 56: 584-587.

Stupnicka E., 1987. Geologia regionalna Polski. Wydawnictwa Geologiczne, Warszawa.

Zgłobicki W., Baran-Zgłobicka B., 2013. Geomorphological Heritage as a Tourist Attraction. A Case Study in Lubelskie Province, SE Poland. Geoheritage 5: 137-149. 